\title{
EVALUATION OF ANTIMICROBIAL AND CYTOTOXIC ACTIVITIES OF PLANT EXTRACTS FROM SOUTHERN MINAS GERAIS CERRADO
}

\author{
Juliana Moscardini CHAVASCO, Bárbara Helena Muniz PRADO E FELIPHE, Claudio Daniel CERDEIRA Fabrício Damasceno LEANDRO, \\ Luiz Felipe Leomil COELHO, Jéferson Junior da SILVA, Jorge Kleber CHAVASCO \& Amanda Latercia Tranches DIAS
}

\begin{abstract}
SUMMARY
The antimicrobial activity of plant hidroethanolic extracts on bacteria Gram positive, Gram negative, yeasts, Mycobacterium tuberculosis $\mathrm{H} 37$ and Mycobacterium bovis was evaluated by using the technique of Agar diffusion and microdilution in broth. Among the extracts evaluated by Agar diffusion, the extract of Bidens pilosa leaf presented the most expressive average of haloes of growth inhibition to the microorganisms, followed by the extract of B. pilos a flower, of Eugenia pyriformis' leaf and seed, of Plinia cauliflora leaf which statistically presented the same average of haloes inhibitory formation on bacteria Gram positive, Gram negative and yeasts. The extracts of Heliconia rostrata did not present activity. Mycobacterium tuberculosis $\mathrm{H} 37$ and Mycobacterium bovis (BCG) appeared resistant to all the extracts. The susceptibility profile of Candida albicans and Saccharomyces cerevisiae fungi were compared to one another and to the Gram positive Bacillus subtilis, Enterococcus faecalis and the Gram negative Salmonella typhimurium bacteria $(p>0.05)$. The evaluation of cytotoxicity was carried out on C6-36 larvae cells of the Aedes albopictus mosquito. The extracts of stem and flower of Heliconia rostrata, leaf and stem of Plinia cauliflora, seed of Anonna crassiflora and stem, flower and root of $B$. pilosa did not present toxicity in the analyzed concentrations. The highest rates of selectivity appeared in the extracts of stem of $A$. crassiflora and flower of B. pilosa to Staphylococcus aureus, presenting potential for future studies about a new drug development.
\end{abstract}

KEYWORDS: Plant extracts; Antimicrobial activity; Mycobacterium tuberculosis; Mycobacterium bovis; Cytotoxicity.

\section{INTRODUCTION}

The indiscriminate use of antimicrobials by population in general has been causing serious public health problems all over the world due to the fact that the microorganisms have the ability to develop resistance to these therapeutic agents ${ }^{29}$.

Bacteria which belong to the Mycobacterium type, mainly the Mycobacterium tuberculosis has been presenting resistance to the antibiotics, probably, due to the long treatment time and to the adverse drug effects, factors which make patients decline the treatment ${ }^{42}$.

Nowadays, there is a great interest from the pharmaceutical industries in the use of biodiversity as a source of new medicine ${ }^{4}$, and the pharmaceutical industries' integration with universities that are studying bioprospective natural resources in search of new medicines has stood out as being increasingly more important ${ }^{26}$.

Among the plants found in the southern cerrado of Minas Gerais, Bidens pilosa Linné, known as Picão preto, is widely used in the traditional medicine as an anti-flu, for diabetes control, as a treatment for gastroenteritis and hepatitis ${ }^{6}$, in buccal antissepsia and anti-jaundiced ${ }^{33}$. Some compound classes like flavonoids and polyacetylenes were isolated from Bidens pilosa ${ }^{30}$.

Eugenia pyriformis Cambess, popularly known as uvaia, has a yellow fruit, is edible and may be used to make juices, vinegar and wine ${ }^{1,16}$. According to STIEVEN et al., (2009) ${ }^{40}$ the fruit of Eugenia pyriformis has bacteriostatic activity when compared to isolates of Escherichia coli, Staphylococcus aureus and Enterococcus faecalis.

Annona crassiflora Mart is a fruitlike species and exclusive from the Brazilian cerrado, known as araticum and marolo ${ }^{25}$. Phytochemical study conducted by GONÇALVES et al., (2009) ${ }^{20}$ with the stem of Anonna crassiflora Mart resulted in obtaining alkaloids with antimicrobial activity.

Plinia cauliflora Berg, known as the jabuticaba tree, is a fruit tree belonging to the Myrtaceae family, spontaneously growing in large parts of Brazil. The bark is astringent, useful against diarrhea and skin irritations. We also have indications in folk medicine as anti-asthmatic medicine, for bowels inflammation and hemoptysis ${ }^{27}$. 


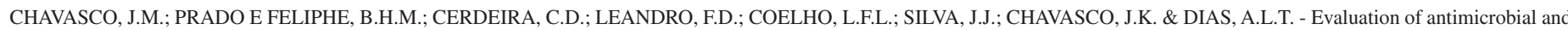
cytotoxic activities of plant extracts from Southern Minas Gerais Cerrado. Rev. Inst. Med. Trop. Sao Paulo, 56(1): 13-20, 2014.

There have been few studies surrounding the Heliconia genus and the number of existing species is still not certain ${ }^{23}$. Among the various species, there is the Heliconia rostrata also known as banana garden tree.

The need for new antimicrobial substances reinforces the growing investigation of the therapeutic potential of medicinal plants, where some of its compounds with the antimicrobial property such as flavonoids, alkaloids, sterols and saponins have been the subject of interest in the treatment of various human infections ${ }^{34,43}$.

COWAN (1999) ${ }^{13}$ reported, based on studies of this literature, that the antimicrobial activity of flavonoids is possibly due to the ability of this group to complex with extracellular and soluble proteins and also with the bacterial cell wall. The mechanism of the antimicrobial action of tannins can be explained by three hypotheses. The first assumes tannins inhibiting bacterial and fungal enzymes and/or complexing with the enzyme substrates and, the second includes the action of tannins on the cell membranes of the microorganisms, altering metabolism, and the third is based on the complexation of macromolecules with metal ions, reducing the availability of ions essential for microbial metabolism ${ }^{36}$.

The ability of saponins to form complexes with steroids, proteins and phospholipids of cell membranes may change its permeability or even lead to its destruction ${ }^{37}$.

Alkaloids are complex compounds, basic in nature, defined by the amine function, which provides its constituents, chemical properties that are related to a high toxicity and a remarkable pharmacological activity. Isolated compounds and plant extracts rich in alkaloids, have demonstrated antimicrobial activity in several studies ${ }^{5}$.

With the development of this research, we aimed to study the feasibility of using the plant extracts found in Southern cerrado area of Minas Gerais State as probable antimicrobial agents with potential action on bacteria and fungi, besides the knowledge of the cytotoxic potential of these extracts. This study will significantly contribute to national and international research aimed at the bio-prospecting of new bioactive plants, safe in accordance with the clinical point of view, which have the potential to be future drug candidates for their use in antimicrobial therapeutic regimens.

\section{MATERIALS AND METHODS}

Plant collection and identification: The Bidens pilosa samples were collected in January 2011, at Jatobá Neighborhood, in Pouso Alegre city MG $\left(22^{\circ} 27^{\prime} 75^{\prime}\right.$ ' S, $\left.18^{\circ} 45^{\prime} 90^{\prime \prime} \mathrm{W}\right)$. The collection of stem samples, leaves and fruits of adult Eugenia pyriformis was conducted in Alfenas countryside - MG (21 ${ }^{\circ} 25^{\prime} 44$ ' S and 45 $56^{\prime}$ 49”'W) in January 2011. Samples of leaf, stem and fruit of adult Plinia cauliflora were collected in January 2011 in the city of Alfenas - MG (21 ${ }^{\circ} 25^{\prime} 44$ ' $\left.\mathrm{S}, 45^{\circ} 56^{\prime} 49^{\prime \prime} \mathrm{W}\right)$. The collections of leaves, flowers, pseudostem and rhizome of Heliconia rostrata were held in Areado city - MG (21 ${ }^{\circ} 24^{\prime} 39.44^{\prime \prime} \mathrm{S}$ and $\left.46^{\circ} 08^{\prime} 53.81^{\prime \prime} \mathrm{W}\right)$ in January 2011. A fruit sample, stem and leaf of Annona crassiflora was held in Alterosa city, $\left(21^{\circ} 8,50.18^{\prime \prime} \mathrm{S}\right.$ and $46^{\circ} 5^{\prime}$ '06.13" W) in March 2011. The plant samples are deposited in the Herbarium of the Federal University of Alfenas (UNIFAL-MG), receiving the following tumble numbers: Bidens pilosa (1745), Eugenia pyriformis (1459), Plinia cauliflora (1637), Heliconia rostrata (1636), Annona crassiflora (1401).
The preparation of the plant extracts: Extracts were prepared from fresh plant parts (leaves, flowers, roots, stems and fruits) in ethyl alcohol $70 \% \mathrm{w} / \mathrm{v}$. After being soaked for seven days, the extracts were filtered, subjected to concentration on rotary evaporator to a negative pressure of $500 \mathrm{mmHg}$ at $60{ }^{\circ} \mathrm{C}$ and, subsequently frozen and lyophilized. Upon use, the lyophilized extracts were relifted in distilled water to obtain concentrations of $100 \mathrm{mg} / \mathrm{mL}$ and then sterilized by filtration.

Microbial strains: The strains studied are recommended by other authors and they are representative of a wide variety of microorganisms that belong to the main bacterial and fungal groups.

Yeasts: Candida albicans ATCC 10231; Saccharomyces cerevisiae ATCC 2601;

Gram positive bacteria: Bacillus subtilis ATCC 6633, Bacillus cereus ATCC 11778, Micrococcus luteus ATCC 9341, Enterococcus faecalis ATCC 51299 and Staphylococcus aureus ATCC 6538;

Gram negative bacteria: Escherichia coli ATCC 25922, Serratia marcescens LMI-UNIFAL, Pseudomonas aeruginosa ATCC 27853, Proteus mirabilis ATCC 25922, Salmonella typhimurium ATCC 14028 Enterobacter cloacae LMI-UNIFAL.

Mycobacteria: Mycobacterium bovis (BCG strain) ATCC 27289 and Mycobacterium tuberculosis (H37) ATCC 27294.

Evaluation of antimicrobial activity of the extracts: The antimicrobial activity was evaluated by agar diffusion through the method defined in document M7A6 (CLSI, 2003) ${ }^{9}$ for bacteria, M24A2 (CLSI, 2008) $)^{11}$ for Mycobacterium spp. and M44A2 (CLSI, 2009) ${ }^{8}$ for fungi. Mueller Hinton agar was used for bacteria and Mueller Hinton agar supplemented with $2 \%$ glucose was used for yeasts.

The activity on Mycobacterium bovis and Mycobacterium tuberculosis was determined by agar diffusion method in Middlebrook 7H10 agar medium with Middlebrook OADC Enrichment ${ }^{\circledR}$. The herbal extracts, $100 \mathrm{mg} / \mathrm{mL}$, in a volume of $10 \mu \mathrm{L}$, were placed on filter paper disks of $10 \mathrm{~mm}$ diameter and dried at $37{ }^{\circ} \mathrm{C}$. The Middlebrook $7 \mathrm{H} 10$ agar was inoculated with a suspension of $M$. bovis and M. tuberculosis with a turbidity corresponding to the Mac Farland 0.5 range. The disks containing the extracts were placed on the surface of the culture medium. Cultures were incubated at $37^{\circ} \mathrm{C}$ for 28 days.

The minimum inhibitory concentration (MIC) was assessed through broth microdilution according to the methodology proposed in document M27A3 (CLSI, 2008) ${ }^{10}$ and with concentration range from $50 \mathrm{mg} / \mathrm{mL}$ to $0.010 \mathrm{mg} / \mathrm{mL}$. The MIC for M. bovis and M. tuberculosis was determined in Middlebrook 7H10 agar dilution in concentrations of $50 \mathrm{mg} / \mathrm{mL}$, $25 \mathrm{mg} / \mathrm{mL}$ and $12.5 \mathrm{mg} / \mathrm{mL}$. The tests were performed in triplicate at different days.

Evaluation of the cytotoxic activity of the plant extracts on cell culture: Cytotoxicity was assessed by MTT method [3 (4,5-Dimethylthiazol-2-yl)-2,5-diphenyltetrazolium bromide]. In this test $1 \times 10^{4}$ cells (derived from Aedes albopictus larvae) were seeded per well in 96-well plates, containing L-15 medium. $0.1 \mathrm{~mL}$ of L-15 medium containing $1 \%$ fetal bovine serum with decreasing dilutions of 


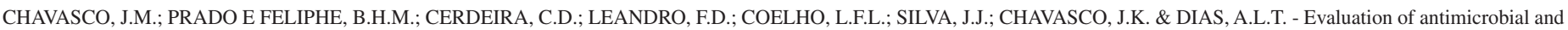
cytotoxic activities of plant extracts from Southern Minas Gerais Cerrado. Rev. Inst. Med. Trop. Sao Paulo, 56(1): 13-20, 2014.

the extracts (from $5 \mathrm{mg} / \mathrm{mL}$ to $0.039 \mathrm{mg} / \mathrm{mL}$ ) was added to the culture. After incubation, $10 \mu \mathrm{L}$ of MTT at a concentration of $5 \mathrm{mg} / \mathrm{mL}$ was added and incubated for four hours at room temperature to a MTT incorporation and the formation of formazan crystals. Spectrophotometric analysis was performed in microplate reader at $600 \mathrm{~nm}$. The percentage of cytotoxicity was calculated using the $[(\mathrm{AB}) / \mathrm{A} X 100]$ formula, where A and B are values of optical densities of treated and controlled cells, respectively. The values of cytotoxic concentration (CC50 and CC 90$)^{2}$ were stablished.

Determination of the plant extract selectivity index: The selectivity index of the extracts was calculated by evaluating the ratio between the CC50 and MIC50 ${ }^{21}$. Values greater than 1 were considered promising for the selection of extracts for further studies.

Evaluation of phytochemical profile of the extracts: In phytochemical screening the following groups of active ingredients were surveyed: flavonoids, the Shinoda reaction technique and alkalis hydroxide reaction; tannins through precipitation method with iron salts, lead acetate, alkaloids, gelatin and copper acetate; alkaloids through precipitation method with Mayer, Bertrand, and Dragendorff Bouchardat reactives; steroids, the Liebermann-Burchard reaction; saponins, through the stir of aqueous extract with persistent foam formation and anthraquinones through direct Borntrager reaction ${ }^{12}$.

Statistical analysis: The data were statistically considered by variance analyses (ANOVA) and Scott-Knott test at 5\% significance (Sisvar Software version 5.3, 2010).

\section{RESULTS AND DISCUSSION}

Evaluation of antimicrobial activity of Bidens pilosa extracts: The stem extract showed activity against four microorganisms: $S$. aureus, $M$. luteus, C. albicans and S. cerevisiae. The largest inhibition zone, in absolute value was observed for M. luteus. The flower and leaf extracts inhibited the growth of 10 microorganisms and the largest inhibition zone, in absolute figure was observed for $S$. cerevisiae. The leaf extract of Bidens pilosa showed the most significant average haloes of growth inhibition when compared among the microorganisms $(p<0.05)$. The largest zones of inhibition were observed at $S$. aureus, M. luteus, $S$. typhimurium, B. cereus, E. coli, C. albicans and $S$. cerevisiae. The leaf extract showed no activity against $P$. aeruginosa, $B$. subtilis, E. faecalis. The smallest halo of growth inhibition was observed for $S$. marcescens. The stem extract showed no activity against Gram negative bacteria. The smallest inhibition zones were observed for $C$. albicans and S. cerevisiae. The flower extract showed no activity against $P$. aeruginosa, $B$. subtilis, E. faecalis, M. bovis and M. tuberculosis. According to the results shown in Table 1 we can see that the root extract of $B$. pilosa did not inhibit the growth of microorganisms.

MOTSEI et al., $(2003)^{28}$ and DEBA et al., (2008) ${ }^{15}$, without specifying the source of the extract showed that B. pilosa has antifungal activity, similar to our results, however both yeasts showed no susceptibility to the root extract of $B$. pilosa. ROJAS et al., (2006) ${ }^{33}$ also without specifying the source of the extract, showed that $B$. pilos a presents growth inhibitory activity on B. cereus, E. coli and $S$. aureus, similar to our results, verifying that these bacteria weren't susceptible to the root extract of $B$. pilosa.

Related to MIC determination, the values varied from $1.56 \mathrm{mg} / \mathrm{mL}$ to
$25 \mathrm{mg} / \mathrm{mL}$. S. aureus was shown to be the most susceptible to the extract of flower whose MIC was $1.56 \mathrm{mg} / \mathrm{mL}$ (Table 1). In phytochemical tests, the root extract showed tannin and saponin in its composition. The stem extracts showed alkaloid, tannin and saponin. The leaf and flower extracts showed alkaloid, flavonoid, tannin and saponin (Table 2). Results similar to OLIVEIRA et al., (2004) ${ }^{30}$ and MARTINS et al., $(2000)^{24}$, without specifying the source of the extract, found flavonoids and tannins, respectively. Considering the wealth of constituents that these extracts present, antimicrobial activity may be related to the presence of compounds like tannins, saponins, flavonoids and alkaloids found, yet these compounds have demonstrated antimicrobial activity.

Evaluation of antimicrobial activity of Eugenia pyriformis Cambess extracts: According to the results presented in Table 1 we see that the leaf extract of E. pyriformis inhibited the growth of all microorganisms, with the exception of $M$. bovis and M. tuberculosis. The largest diameter of inhibition zone in terms of absolute value was observed for M. luteus. The diameter of inhibition haloes was compared among Gram positive and Gram negative bacteria. There were also inhibition haloes against the $S$. cerevisiae and $C$. albicans yeasts. The stem extract inhibited the growth of ten microorganisms $(67 \%)$. The largest diameter of inhibition zone was observed for M. luteus, while for $S$. marcescens and $P$. aeruginosa the lowest diameters were found. The fruit extract inhibited the growth of nine microorganisms (60\%). The extract showed no activity against $P$. mirabilis, E. coli, $C$. albicans, S. cerevisiae, M. bovis and M. tuberculosis.

The seed extract inhibited the growth of $13(87 \%)$ of the 15 microorganisms. The extract did not show activity against $S$. marcescens. The largest diameter of inhibition zone was verified to M. luteus. The extract showed antifungal activity against $S$. cerevisiae and $C$. albicans. In our study, the fruit extract showed antimicrobial activity against E. faecalis and S. aureus and P. aeruginosa, unlike STIEVEN et al., $(2009)^{40}$, who found activity against $E$. coli and found no activity against $P$. aeruginosa. This difference may be related to the origin of the plant extracts, because the ATCC strain that we evaluated was the same as Stieven group.

The leaf extracts showed alkaloid, flavonoid, tannin and saponin. The extracts showed stem tannin and saponin in their composition. The seed extracts showed alkaloids, tannins and saponins (Table 1). The results of this study are similar to ARMSTRONG's $(2011)^{3}$ which found flavonoids, tannins and saponins in the extracts. Considering the presence of compounds such as tannins, saponins, flavonoids and alkaloids, which present proven antimicrobial activity, it is concluded that the antimicrobial activity of the extracts may be related to the presence of these compounds. Regarding the MIC the values ranged from 12.50 to $50 \mathrm{mg} / \mathrm{mL}$.

Evaluation of antimicrobial activity of Annona crassiflora Mart extracts: In Table 1 we can see that the leaf extract of $A$. crassiflora inhibited the growth of six (40\%) of the 15 microorganisms tested: $S$. aureus, M. luteus, P. mirabilis, B. subtilis, E. faecalis and B. cereus. Comparing the size of inhibition haloes, in absolute values, we conclude that the Gram positive had a higher susceptibility than the Gram negative. The leaf extract did not show antimicrobial activity on yeasts. The stem extract inhibited the growth of seven $(47 \%)$ of the 15 microorganisms tested. The extract did not show activity against $E$. cloacae, $P$. aeruginosa, S. marcescens, E. coli, C. albicans, S. cerevisae, M. bovis and M. 
CHAVASCO, J.M.; PRADO E FELIPHE, B.H.M.; CERDEIRA, C.D.; LEANDRO, F.D.; COELHO, L.F.L.; SILVA, J.J.; CHAVASCO, J.K. \& DIAS, A.L.T. - Evaluation of antimicrobial and cytotoxic activities of plant extracts from Southern Minas Gerais Cerrado. Rev. Inst. Med. Trop. Sao Paulo, 56(1): 13-20, 2014.

Table 1

Evaluation of antimicrobial activity (agar diffusion and broth microdilution), cytotoxicity and selectivity index of plant extracts from cerrado in the south of Minas Gerais.

\begin{tabular}{|c|c|c|c|c|c|c|c|c|c|c|c|c|c|c|c|c|c|c|c|c|c|c|c|c|}
\hline \multirow{2}{*}{$\begin{array}{l}\text { Microorga- } \\
\text { nism/Test }\end{array}$} & \multirow{2}{*}{$\frac{\text { Plant }}{\text { Fraction }}$} & \multicolumn{4}{|c|}{ Heliconia rostrata } & \multicolumn{3}{|c|}{ Plinia cauliflora } & \multicolumn{5}{|c|}{ Anonna crassiflora } & \multicolumn{4}{|c|}{ Bidens pilosa } & \multicolumn{4}{|c|}{ Eugenia pyriformis } & \multicolumn{3}{|c|}{ Controls } \\
\hline & & $\mathrm{Ca}$ & $\mathrm{Fl}$ & Fo & Riz & $\mathrm{CF}$ & Fo & $\mathrm{Ca}$ & $\mathrm{CF}$ & $\mathrm{Ca}$ & $\mathrm{Se}$ & Po & Fo & $\mathrm{Ra}$ & $\mathrm{Ca}$ & $\mathrm{Fl}$ & Fo & Fo & $\mathrm{Ca}$ & $\mathrm{Fr}$ & $\mathrm{Se}$ & $\mathrm{Cl}$ & $\mathrm{Ri}$ & $\mathrm{Ag}$ \\
\hline & & \multicolumn{23}{|c|}{ Results } \\
\hline \multirow{3}{*}{$\begin{array}{l}\text { Bacillus } \\
\text { cereus }\end{array}$} & MH & 0 & 0 & 0 & 0 & 14 & 14 & 9 & 15.3 & 10 & 0 & 9 & 13 & 0 & 0 & 17.3 & 18 & 15 & 11.5 & 12.3 & 14.7 & 13 & --- & 0 \\
\hline & MIC & $\mathrm{N}$ & $\mathrm{N}$ & $\mathrm{N}$ & $\mathrm{N}$ & 50 & 50 & 25 & 50 & 50 & $\mathrm{~N}$ & 50 & 25 & $\mathrm{~N}$ & $\mathrm{~N}$ & 12.5 & 12.5 & 25 & 12.5 & 12.5 & 25 & ---- & ---- & ---- \\
\hline & SI & NA & $\mathrm{NA}$ & NA & NA & 0.026 & NA & NA & 0.04120 & 0.1172 & NA & 0.0536 & 60.1544 & NA & $\mathrm{NA}$ & 0.2256 & NA & 0.3822 & NA & 0.16880 & 0.0504 & ----- & ----- & - \\
\hline \multirow{3}{*}{$\begin{array}{l}\text { Bacillus } \\
\text { subtilis }\end{array}$} & $\mathrm{MH}$ & 0 & 0 & 0 & 0 & 10 & 11.7 & 7.3 & 11.3 & 10.3 & 0 & 0 & 11.3 & 0 & 0 & 0 & 0 & 13.7 & 11.3 & 10.3 & 13 & 15.3 & +---- & 0 \\
\hline & MIC & $\mathrm{N}$ & $\mathrm{N}$ & $\mathrm{N}$ & $\mathrm{N}$ & 50 & 50 & 50 & 50 & 25 & $\mathrm{~N}$ & $\mathrm{~N}$ & 50 & $\mathrm{~N}$ & $\mathrm{~N}$ & $\mathrm{~N}$ & $\mathrm{~N}$ & 25 & 25 & 50 & 50 & ----- & ----- & ----- \\
\hline & SI & NA & NA & NA & NA & 0.026 & $\mathrm{NA}$ & NA & 0.04120 & 0.2344 & NA & $\mathrm{NA}$ & 0.0722 & NA & NA & NA & NA & 0.3824 & NA & 0.04220 & 0.0252 & ----- & ----- & ----- \\
\hline \multirow{3}{*}{$\begin{array}{l}\text { Enterococ- } \\
\text { cus faecalis }\end{array}$} & $\mathrm{MH}$ & 0 & 0 & 0 & 0 & 13.7 & 12.7 & 7.3 & 15 & 8.3 & 0 & 9 & 14.3 & 0 & 0 & 0 & 0 & 13.7 & 10 & 10.3 & 12 & 14 & ----- & 0 \\
\hline & MIC & $\mathrm{N}$ & $\mathrm{N}$ & $\mathrm{N}$ & $\mathrm{N}$ & 50 & 50 & 25 & 25 & 25 & $\mathrm{~N}$ & 50 & 25 & $\mathrm{~N}$ & $\mathrm{~N}$ & $\mathrm{~N}$ & $\mathrm{~N}$ & 50 & 50 & 50 & 50 & ----- & ---- & ---- \\
\hline & SI & NA & NA & NA & NA & 0.026 & NA & NA & 0.08240 & 0.2344 & NA & 0.0536 & 60.1544 & NA & NA & NA & NA & 0.1912 & NA & 0.04220 & 0.0252 & ----- & ----- & ----- \\
\hline & MH & 0 & 0 & 0 & 0 & 16.3 & 18.3 & 18.3 & 19 & 15 & 0 & 13 & 13.7 & 0 & 15.7 & 23.3 & 23.7 & 18 & 14.7 & 19.3 & 18 & 20 & ----- & 0 \\
\hline & MIC & $\mathrm{N}$ & $\mathrm{N}$ & $\mathrm{N}$ & $\mathrm{N}$ & 50 & 25 & 25 & 12.5 & 25 & $\mathrm{~N}$ & 50 & 50 & $\mathrm{~N}$ & 25 & 25 & 25 & 50 & 50 & 50 & 25 & ----- & ----- & ----- \\
\hline & SI & NA & NA & NA & NA & 0.026 & NA & NA & 0.16480 & 0.2344 & NA & 0.0536 & 60.0772 & NA & 0.1564 & 40.1128 & NA & 0.1912 & NA & 0.04220 & 0.0504 & ----- & ------ & --- \\
\hline & $\mathrm{MH}$ & 0 & 0 & 0 & 0 & 15.3 & 16.7 & 13 & 18 & 12 & 0 & 16 & 12 & 0 & 14.3 & 22 & 26.3 & 12 & 11.3 & 12 & 13.7 & 16.3 & ----- & 0 \\
\hline & MIC & $\mathrm{N}$ & $\mathrm{N}$ & $\mathrm{N}$ & $\mathrm{N}$ & 25 & 50 & 6.25 & 6.25 & 1.56 & $\mathrm{~N}$ & 12.5 & 25 & $\mathrm{~N}$ & 25 & 1.56 & 25 & 25 & 25 & 12.5 & 25 & ----- & ---- & ----- \\
\hline & SI & NA & NA & NA & NA & 0.052 & NA & NA & 0.3296 & 3.76 & NA & 0.1072 & 20.1544 & NA & 0.1564 & $\begin{array}{r}4 \quad 1.81 \\
\end{array}$ & NA & 0.3824 & NA & 0.16880 & 0.0504 & ----- & ----- & ---.. \\
\hline & $\mathrm{MH}$ & 0 & 0 & 0 & 0 & 7.3 & 10.3 & 8 & 0 & 0 & 0 & 0 & 0 & 0 & 0 & 10.3 & 12.7 & 12 & 0 & 12 & 10.3 & 13.7 & ---- & 0 \\
\hline & MIC & $\mathrm{N}$ & $\mathrm{N}$ & $\mathrm{N}$ & $\mathrm{N}$ & 50 & 25 & 25 & $\mathrm{~N}$ & $\mathrm{~N}$ & $\mathrm{~N}$ & $\mathrm{~N}$ & $\mathrm{~N}$ & $\mathrm{~N}$ & $\mathrm{~N}$ & 25 & 50 & 25 & $\mathrm{~N}$ & 12.5 & 50 & ----- & ----- & ----- \\
\hline & SI & NA & NA & NA & NA & 0.026 & NA & NA & NA & NA & NA & NA & NA & NA & $\mathrm{NA}$ & 0.1128 & NT & 0.3824 & NA & 0.16880 & 0.0252 & ----- & ------ & ----- \\
\hline & MH & 0 & 0 & 0 & 0 & 11.3 & 10.3 & 12.3 & 0 & 0 & 0 & 0 & 0 & 0 & 0 & 12 & 16.3 & 11.3 & 0 & 0 & 9.7 & 14 & ----- & 0 \\
\hline la & MIC & $\mathrm{N}$ & $\mathrm{N}$ & $\mathrm{N}$ & $\mathrm{N}$ & 25 & 25 & 50 & $\mathrm{~N}$ & $\mathrm{~N}$ & $\mathrm{~N}$ & $\mathrm{~N}$ & $\mathrm{~N}$ & $\mathrm{~N}$ & $\mathrm{~N}$ & 25 & 25 & 12.5 & $\mathrm{~N}$ & $\mathrm{~N}$ & $\mathrm{~N}$ & ----- & ----- & ---- \\
\hline & SI & NA & NA & NA & NA & 0.052 & NA & NA & NA & NA & NA & NA & NA & NA & NA & 0.1128 & NT & 0.7648 & NT & NA 0 & 0.0252 & ----- & ----- & ------ \\
\hline & MH & 0 & 0 & 0 & 0 & 8.3 & 13.7 & 10.3 & 16 & 10 & 0 & 12 & 13.3 & 0 & 0 & 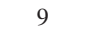 & 11 & 13.4 & 11.3 & 0 & 11 & 6 & ----- & 0 \\
\hline & MIC & $\mathrm{N}$ & $\mathrm{N}$ & $\mathrm{N}$ & $\mathrm{N}$ & 50 & 50 & 25 & 50 & 50 & $\mathrm{~N}$ & 50 & 25 & $\mathrm{~N}$ & $\mathrm{~N}$ & 50 & 50 & 50 & 50 & $\mathrm{~N}$ & 50 & ----- & ----- & ---- \\
\hline & SI & NA & NA & NA & NA & 0.026 & NA & NA & 0.04120 & 0.1172 & NA & 0.0536 & 60.1544 & NA & NA & 0.0564 & NA & 0.1912 & NA & NA 0 & 0.0252 & ----- & ------ & ------ \\
\hline eudo- & $\mathrm{MH}$ & 0 & 0 & 0 & 0 & 9 & 13.7 & 9.7 & 0 & 0 & 0 & 0 & 0 & 0 & 0 & 0 & 0 & 10 & 8 & 9.7 & 10.3 & 12 & ----- & 0 \\
\hline & MIC & $\mathrm{N}$ & $\mathrm{N}$ & $\mathrm{N}$ & $\mathrm{N}$ & 50 & 50 & 50 & $\mathrm{~N}$ & $\mathrm{~N}$ & $\mathrm{~N}$ & $\mathrm{~N}$ & $\mathrm{~N}$ & $\mathrm{~N}$ & $\mathrm{~N}$ & $\mathrm{~N}$ & $\mathrm{~N}$ & 50 & 50 & 50 & 50 & ----- & ----- & ----- \\
\hline uginosa & SI & NA & NA & NA & NA & 0.026 & NA & NA & NA & NA & NA & NA & NA & NA & NA & NA & NA & 0.1912 & NA & 0.04220 & 0.0252 & ---- & ----- & ---- \\
\hline & $\mathrm{MH}$ & 0 & 0 & 0 & 0 & 7.3 & 7.7 & 8 & 8 & 7.3 & 0 & 0 & 0 & 0 & 0 & 16 & 24 & 10 & 14.3 & 10.3 & 12 & 12.3 & ----- & 0 \\
\hline $\begin{array}{l}\text { nonella } \\
\text { imurium }\end{array}$ & MIC & $\mathrm{N}$ & $\mathrm{N}$ & $\mathrm{N}$ & $\mathrm{N}$ & 50 & 50 & 50 & 50 & 50 & $\mathrm{~N}$ & $\mathrm{~N}$ & $\mathrm{~N}$ & $\mathrm{~N}$ & $\mathrm{~N}$ & 25 & 25 & 50 & 50 & 50 & 50 & ----- & ---- & ---- \\
\hline & SI & NA & NA & NA & NA & 0.026 & NA & NA & 0.04120 & 0.1172 & NA & NA & $\mathrm{NA}$ & NA & $\mathrm{NA}$ & 0.1128 & NA & 0.1912 & NA & 0.04220 & 0.0252 & ----- & ----- & ---- \\
\hline & MH & 0 & 0 & 0 & 0 & 10 & 8.7 & 8 & 0 & 0 & 0 & 0 & 0 & 0 & 0 & 11.7 & 10.7 & 10 & 8 & 8 & 0 & 3.7 & ----- & 0 \\
\hline & MIC & $\mathrm{N}$ & $\mathrm{N}$ & $\mathrm{N}$ & $\mathrm{N}$ & 25 & 25 & 25 & $\mathrm{~N}$ & $\mathrm{~N}$ & $\mathrm{~N}$ & $\mathrm{~N}$ & $\mathrm{~N}$ & $\mathrm{~N}$ & $\mathrm{~N}$ & 25 & 25 & 25 & 50 & 25 & $\mathrm{~N}$ & ----- & ---- & ----- \\
\hline & SI & NA & NA & NA & NA & 0.052 & NA & NA & NA & NA & NA & NA & NA & NA & $\mathrm{NA}$ & 0.1128 & NA & 0.3824 & NA & 0.0844 & $\mathrm{NA}$ & ----- & ----- & ---- \\
\hline & MH & 0 & 0 & 0 & 0 & 0 & 0 & 0 & 0 & 0 & 0 & 0 & 0 & 0 & 0 & 0 & 0 & 0 & 0 & 0 & 0 & ---- & 26.3 & 0 \\
\hline $\begin{array}{l}\text { cte- } \\
\text { vis }\end{array}$ & MIC & $\mathrm{N}$ & $\mathrm{N}$ & $\mathrm{N}$ & $\mathrm{N}$ & $\mathrm{N}$ & $\mathrm{N}$ & $\mathrm{N}$ & $\mathrm{N}$ & $\mathrm{N}$ & $\mathrm{N}$ & $\mathrm{N}$ & $\mathrm{N}$ & $\mathrm{N}$ & $\mathrm{N}$ & $\mathrm{N}$ & $\mathrm{N}$ & $\mathrm{N}$ & $\mathrm{N}$ & $\mathrm{N}$ & $\mathrm{N}$ & ---- & ----- & ---- \\
\hline & SI & NA & NA & NA & NA & NA & NA & NA & NA & NA & NA & NA & $\mathrm{NA}$ & NA & NA & NA & NA & $\mathrm{NA}$ & NA & $\mathrm{NA}$ & $\mathrm{NA}$ & ----- & ---- & ----- \\
\hline$a c-$ & $\mathrm{MH}$ & 0 & 0 & 0 & 0 & 0 & 0 & 0 & 0 & 0 & 0 & 0 & 0 & 0 & 0 & 0 & 0 & 0 & 0 & 0 & 0 & ---- & 26.3 & 0 \\
\hline & MIC & $\mathrm{N}$ & $\mathrm{N}$ & $\mathrm{N}$ & $\mathrm{N}$ & $\mathrm{N}$ & $\mathrm{N}$ & $\mathrm{N}$ & $\mathrm{N}$ & $\mathrm{N}$ & $\mathrm{N}$ & $\mathrm{N}$ & $\mathrm{N}$ & $\mathrm{N}$ & $\mathrm{N}$ & $\mathrm{N}$ & $\mathrm{N}$ & $\mathrm{N}$ & $\mathrm{N}$ & $\mathrm{N}$ & $\mathrm{N}$ & ---- & ---- & ---- \\
\hline & SI & NT & NT & NT & NT & NT & NT & NT & NT & NT & NT & NT & NT & NT & NT & NT & NT & NT & NT & NT & NT & ----- & ------- & ------ \\
\hline & $\mathrm{MH}$ & 0 & 0 & 0 & 0 & 0 & 11.7 & 0 & 0 & 0 & 0 & 0 & 0 & 0 & 13.3 & 24 & 28 & 10.3 & 10.3 & 0 & 15 & 15.3 & ------- & 0 \\
\hline $\begin{array}{l}\text { alda } \\
\text { icans }\end{array}$ & MIC & $\mathrm{N}$ & $\mathrm{N}$ & $\mathrm{N}$ & $\mathrm{N}$ & $\mathrm{N}$ & 50 & $\mathrm{~N}$ & $\mathrm{~N}$ & $\mathrm{~N}$ & $\mathrm{~N}$ & $\mathrm{~N}$ & 0 & $\mathrm{~N}$ & 25 & 25 & 12.5 & 12.5 & 50 & $\mathrm{~N}$ & 25 & ---- & ---- & ---- \\
\hline & SI & NA & NA & NA & NA & NA & NA & NA & NA & NA & NA & NA & NA & NA & 0.1584 & 40.1128 & NT & 0.7648 & NA & NA 0 & 0.0504 & ------ & ----- & ----- \\
\hline & MH & 0 & 0 & 0 & 0 & 11.5 & 8.3 & 8.7 & 0 & 0 & 0 & 0 & 0 & 0 & 13.3 & 26.7 & 29.3 & 12.3 & 0 & 0 & 14 & 18.7 & ------ & 0 \\
\hline $\begin{array}{l}\text { charomy- } \\
\text { cerevisae }\end{array}$ & MIC & $\mathrm{N}$ & $\mathrm{N}$ & $\mathrm{N}$ & $\mathrm{N}$ & 50 & 50 & 25 & $\mathrm{~N}$ & $\mathrm{~N}$ & $\mathrm{~N}$ & $\mathrm{~N}$ & $\mathrm{~N}$ & $\mathrm{~N}$ & 25 & 12.5 & 12.5 & 25 & $\mathrm{~N}$ & $\mathrm{~N}$ & 50 & ----- & ---- & ---- \\
\hline & SI & NA & NA & NA & NA & 0.026 & NA & NA & NA & NA & NA & NA & $\mathrm{NA}$ & NA & 0.1564 & 40.2256 & NA & 0.3824 & NA & NA 0 & 0.0252 & ----- & ---- & ---- \\
\hline $\mathrm{C}_{50}$ & & NT & NT & 1.4 & 2.15 & 1.3 & NT & NT & 2.06 & 5.86 & NT & 2.88 & 3.86 & NT & 3.91 & 2.82 & NT & 9.56 & NT & 2.11 & 1.26 & ---- & ---- & ---- \\
\hline $\mathrm{CC}_{90}$ & & NT & NT & 2.6 & 6.9 & 2.55 & NT & NT & 9.38 & 10.77 & NT & 5.98 & 8.03 & NT & 7.27 & 5.41 & NT & 19 & NT & 4.25 & 3.44 & ---- & ---- & ---- \\
\hline
\end{tabular}




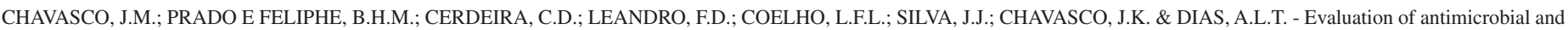
cytotoxic activities of plant extracts from Southern Minas Gerais Cerrado. Rev. Inst. Med. Trop. Sao Paulo, 56(1): 13-20, 2014.

Table 2

Determination of chemical compounds of Anonna crassiflora, Bidens pilosa, Eugenia pyriformis, Heliconia rostrata and Plinia cauliflora plant extracts by phytochemical analysis

\begin{tabular}{|c|c|c|c|c|c|c|}
\hline Plant & Extrat & Alkaloids & Anthraquinones & Flavonoids & Tannins & Saponins \\
\hline \multirow{5}{*}{ Anonna crassiflora } & Fruit Peel & + & - & - & + & - \\
\hline & Stalk & - & - & - & + & - \\
\hline & Seed & - & - & - & - & - \\
\hline & Pulp & + & - & - & - & + \\
\hline & Leaf & + & - & + & - & - \\
\hline \multirow{4}{*}{ Bidens pilosa } & Root & - & - & - & + & + \\
\hline & Stalk & + & - & - & + & + \\
\hline & Flower & + & - & + & + & + \\
\hline & Leaf & + & - & + & + & + \\
\hline \multirow{4}{*}{ Eugenia pyriformis } & Leaf & + & - & + & + & + \\
\hline & Stalk & - & - & - & + & + \\
\hline & Fruit & - & - & - & - & - \\
\hline & Seed & + & - & - & + & + \\
\hline \multirow{4}{*}{ Heliconia rostrata } & Stalk & - & - & - & + & + \\
\hline & Flower & - & - & - & - & + \\
\hline & Leaf & - & - & + & + & - \\
\hline & Rizoma & - & - & + & - & - \\
\hline \multirow{3}{*}{ Plinia cauliflora } & Fruit Peel & + & - & - & - & + \\
\hline & Leaf & - & - & + & + & + \\
\hline & Stalk & - & - & - & + & + \\
\hline
\end{tabular}

+ : presence in reactions; - : absence.

tuberculosis microorganisms. The pulp extract inhibited the growth of five (33\%) of the 15 microorganisms tested. The seed extract did not inhibit the growth of any of the microorganisms. The bark extract of the fruit inhibited the growth of seven of the 15 microorganisms tested. The extract showed no activity against $E$. cloacae, $P$. aeruginosa, $S$. marcescens, $E$. coli, C. albicans, S. cerevisiae, M. bovis and M. tuberculosis. The bark extract had greater activity against Gram positive bacteria. SILVA et al., $(2001)^{38}$ conducted experiments with leaf extracts of $A$. crassiflora investigating its activity over 52 strains of $C$. albicans from clinical origin, which showed susceptibility to them. In our study, the evaluated extracts didn't show growth inhibitory activity against $C$. albicans. This difference in results can probably be explained by the technique of obtaining the extract, or by the origin of the plant or by the diversity of strains when isolated from clinical specimens. In relation to MIC the values ranged from 1.56 to $50 \mathrm{mg} / \mathrm{mL}$.

The extracts of fruit showed alkaloid and tannin in their composition. The stem extracts presented tannin in their composition. The fruit pulp extracts showed saponin, while the leaf extracts showed flavonoid and alkaloid (Table 2). Similar results were found by GONÇALVES et al., $(2009)^{20}$ that found alkaloid in phytochemical screening. As these compounds have antimicrobial activity, the obtained results may be related to the presence of the same.
Evaluation of antimicrobial activity of Plinia cauliflora extracts: All tested microorganisms were susceptible to P. cauliflora extracts, however, $C$. albicans was susceptible only to the leaf extract except for $M$. bovis and $M$. tuberculosis. Among the evaluated microorganisms, $M$. luteus showed greater halo inhibition in absolute value when compared to other microorganisms. In the studies of MACEDO et al. $(2009)^{22}$, the leaf extract showed antimicrobial action on five strains of Streptococcus spp., similar to our results whose leaf extract was active on all Gram positive with MIC values among $6.25 \mathrm{mg} / \mathrm{mL}$ and $50 \mathrm{mg} / \mathrm{mL}$.

Alkaloid and saponin were found in extracts of the fruit skin. Flavonoid, tannin and saponin were found in leaf extracts and tannins and saponins were found in stem extracts (Table 2). In the phytochemical study conducted by REYNERTSON et al. (2006) $)^{32}$, without specifying the extract source, tannin was found in its composition, that is similar to this work result. The antimicrobial activity of P.cauliflora may be related to the presence of flavonoids, alkaloids, saponins and tannins, which have proven antimicrobial activity.

Evaluation of antimicrobial activity of Heliconia rostrata extracts: The results show that $H$. rostrata extracts did not inhibit the growth of the microorganisms, as described in Table 1. According to Table 2, the stem extract presented tannin and saponin in its composition. The flower extracts 


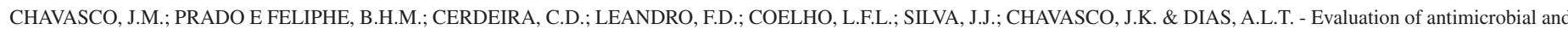
cytotoxic activities of plant extracts from Southern Minas Gerais Cerrado. Rev. Inst. Med. Trop. Sao Paulo, 56(1): 13-20, 2014.

presented saponin. The leaf extracts presented flavonoid and tannin, and rhizone extracts presented flavonoids. Studies about the phytochemical composition of the extracts and antimicrobial activity of $H$. rostrata were not found in literature to be compared to ours. As there is no growth inhibition we can assume that the substances are found in low concentration or that the active compounds are not soluble in liquid extractor, although, many authors have suggested the use of $70 \%$ ethanol as a liquid extractor for plant extracts. Many negative results can also be influenced by external factors intrinsic to the extraction process as the degradation of compounds with antimicrobial activity during the extraction process. Another point to be considered is the influence of external factors in the production of secondary metabolites, such as nutrient availability, interactions with pests, soil, circadian cycle, seasonality, postharvest life and humidity. Despite some extracts do not present antimicrobial activity in agar diffusion tests, they were subjected to MIC determination since discrepancies can occur among the results obtained by these methods, with alterations of the results when the test is performed in a liquid environment.

In general, the hydroethanolic extracts of tested plants showed activity against the Gram positive, Gram negative bacteria and yeasts, however, the MIC values were greater than $1000 \mathrm{mg} / \mathrm{mL}$. According to DALL'AGNOL et al. (2003) $)^{14}$; FABRY et al. (1998) ${ }^{18}$ and TANAKA et al. $(2005)^{41}$ plant extracts are considered to be a promising inhibitory potential and demonstrate antimicrobial activity at concentrations up to $100 \mathrm{mg} / \mathrm{mL}$, a moderate inhibitory activity of $100-500 \mathrm{mg} / \mathrm{mL}$, a weak activity of 500-1000 mg/mL and inactive extracts when MICs are higher than $1000 \mathrm{mg} / \mathrm{mL}$. Therefore, according to this established pattern, the hydroethanolic extracts tested were ineffective.

However, new assessment tests with extracts prepared with other solvents should be conducted. It is known that the chemical composition of an extract is the result of chemical reagents and methods used to obtain it, and that the active components that are usually found in low concentrations and in crude extract may be more diluted (CECHINEL FILHO, 2000) ${ }^{7}$. As there were some different results from those reported in the literature, we conclude that several factors may have influenced the study, from climatic conditions and location of geographic species to the diffusion of the extract used in the experiment as well as the genetic variation of some microbial strains. These findings emphasize the need to standardize and develop the several evaluation methodologies, in order to confirm and ensure the reliability of results obtained in antimicrobial assays with plant extracts.

The development of new studies using other methods of plant extract diffusion is suggested as well as the use of extracts obtained in the presence of other solvents besides other bacterial and fungal strains, when coupled with toxicity tests.

Among the extracts evaluated by agar diffusion method, the leaf extract of B. pilosa showed the most significant average of growth inhibition haloes when compared to the microorganisms used in this study, followed by the flower extracts of B. pilosa, leaves of E. pyriformis and $P$. cauliflora, and E. pyriformis seed which statistically showed the same average formation of inhibitory haloes. Among the tested microorganisms, the Gram positive bacteria M. luteus and $S$. aureus showed the same susceptibility profile $(p>0.05)$. Gram negative bacteria E. coli, E. cloacae, S. marcescens and P. aeruginosa also showed the same susceptibility profile $(p>0.05)$. The susceptibility profile of the fungi $C$. albicans and $S$. cerevisiae were comparable to the Gram positive B. subtilis, E. faecalis and Gram negative bacteria S. typhimurium ( $p>$ 0.05 ). From microorganisms which showed some susceptibility to any of the extracts, M. bovis, P. aeruginosa, S. marcescens, E. cloacae and $E$. coli were statistically also less susceptible. Only the leaf extracts of $B$. pilosa showed statistically significant equality over the average inhibitory effectiveness when compared to the positive control Chlorhexidine.

Evaluation of the cytotoxic activity of the extracts on cell culture: According to results shown in Table 1, the stem and flower extracts of $H$. rostrata, leaf and stem of P.cauliflora, seed of A. crassiflora, stem, flower and root of $B$. pilosa showed no toxicity on the concentrations tested on cell culture. This is the first study that evaluated the antimicrobial and cytotoxic activities of $H$. rostrata species, which is considered a member of a family of plants reported to have antiophidic activities (ESTRADA et al., 2010) ${ }^{17}$. Our results to $B$. pilosa are in accordance with the results of GARCIA et al. $(2011)^{19}$ that found the extracts of B. pilosa didn't present significant cytotoxic activity against a human pulmonary tumor cell line A549. SOUZA-MOREIRA et al. $(2011)^{39}$ evaluated in vitro the cytotoxicity of fruit and leaf extracts of $P$. cauliflora with the fibroblast cell line SIRC CCL 60, and leaf extract showed a considerable $50 \%$ inhibitory concentration of $0.48 \mu \mathrm{g} / \mathrm{mL}$. In the study of SANTOS PIMENTA et al. $(2003)^{35}$, the ethanolic extracts of $A$. crassiflora leaves did not show cytotoxic activity, but the fractions resulting from solvent extraction showed good brine shrimp larvicidal activity. In our study, the cytotoxic concentration for $50 \%$ of cells (CC50) of the extracts ranged from $1.30 \mathrm{mg} / \mathrm{mL}$ to $9.56 \mathrm{mg} / \mathrm{mL}$ and the cytotoxic concentration for $90 \%$ of cells (CC90) of the extracts ranged from $2.55 \mathrm{mg} / \mathrm{mL}$ to $19.00 \mathrm{mg} / \mathrm{mL}$.

KLEYMANN \& WERLING (2004) $)^{21}$ propose the activity selectivity assay format as a new standard in anti-infective drug discovery and clinical development. According to our results, the selectivity index values (SI) for A. crassiflora stem and B. pilosa flower for S. aureus showed values greater than 1 , respectively, 3.76 and 1.86 , showing a promising potential for evaluations like antimicrobial drug candidates in infections treatment caused by $S$. aureus.

\section{RESUMO}

\section{Avaliação das atividades antimicrobiana e citotóxica de extratos de plantas do Cerrado do Sul de Minas Gerais}

Foi avaliada a atividade antimicrobiana de extratos hidroetanólicos de plantas sobre bactérias Gram positiva, Gram negativa, leveduras, Mycobacterium tuberculosis $\mathrm{H} 37$ e Mycobacterium bovis pela técnica de difusão em Agar e microdiluição em caldo. Dentre os extratos avaliados pelo método de difusão em Agar, o extrato da folha de Bidens pilosa apresentou a mais expressiva média de halos de inibição de crescimento frente aos microrganismos, seguido pelo extrato da flor de B. pilosa, da folha e semente de Eugenia pyriformis, da folha de Plinia cauliflora que apresentaram estatisticamente a mesma média de formação de halos inibitórios sobre bactérias Gram positivas, Gram negativas e leveduras. Os extratos de Heliconia rostrata não apresentaram atividade. Mycobacterium tuberculosis H37 e Mycobacterium bovis (BCG) mostraram-se resistentes a todos os extratos. O perfil de sensibilidade dos fungos Candida albicans e Saccharomyces cerevisiae foram comparáveis entre si e entre as bactérias Gram positivas Bacillus subtilis, Enterococcus faecalis e Gram negativa Salmonella typhimurium ( $p>0.05)$. A avaliação 
CHAVASCO, J.M.; PRADO E FELIPHE, B.H.M.; CERDEIRA, C.D.; LEANDRO, F.D.; COELHO, L.F.L.; SILVA, J.J.; CHAVASCO, J.K. \& DIAS, A.L.T. - Evaluation of antimicrobial and cytotoxic activities of plant extracts from Southern Minas Gerais Cerrado. Rev. Inst. Med. Trop. Sao Paulo, 56(1): 13-20, 2014.

da citotoxicidade foi realizada sobre células C6-36 de larvas de mosquito Aedes albopictus. Os extratos de caule e flor de $H$. rostrata, folha e caule de $P$. cauliflora, semente de Anonna crassiflora e caule, flor e raiz de B. pilosa não apresentaram toxicidade nas concentrações avaliadas. Os maiores índices de seletividade foram apresentados pelos extratos de caule de A. crassiflora e flor de B. pilosa para Staphylococcus aureus, apresentando potencial para estudos como futuros candidatos a fármacos.

\section{ACKNOWLEDGMENT}

We thank Professor Dr. Marcelo Polo for plant identification and The Fundação de Amparo à Pesquisa do Estado de Minas Gerais (APQ01684/08; 02782/10, 01413/12).

\section{REFERENCES}

1. Andrade RNB, Ferreira AG. Germination and storing of uvaia seeds (Eugenia pyriformis Camb.) - Myrtaceae. Rev Bras Sementes. 2000;22:118-25.

2. Araújo SAC, Teixeira MFS, Dantas TVM, Miranda AM, Lima FES, Melo VSP, et al. Avaliação in vitro da atividade citotóxica de drogas antivirais em fibroblastos caprinos. Ci Animal. 2008;18:25-31.

3. Armstrong L. Estudos morfoanatômico, fitoquímico e de atividades biológicas de folha e caule de Eugenia pyriformis Cambess, Myrtaceae. [dissertação]. Curitiba: Universidade Federal do Paraná; 2011.

4. Boldi AM. Libraries of natural product-like scaffolds. Curr Opin Chem Biol. 2004;8:281-6.

5. Bruneton J. Pharmacognosy, phytochemistry, medicinal plants. 2 ed. Paris: Lavoisier Publishing / Intercept Ltd; 1999.

6. Chang JS, Chiang LC, Chen CC, Liu LT, Wang KC, Lin CC. Antileukemic activity of Bidens pilosa L. var, minor (Blume) Sherff and Houttuynia cordata Thunb. Am J Chin Med. 2001;29:303-12.

7. Cechinel Filho V. Principais avanços e perspectivas na área de produtos naturais ativos: estudos desenvolvidos no NIQFAR / Univali. Quím Nova. 2000;23:680-5.

8. Clinical and Laboratory Standards Institute (CLSI). Reference method for antifungal disk diffusion susceptibility testing of yeasts. Approved Guideline. $2^{\text {nd }}$ ed. Wayne, PA: CLSI; 2009. p. M44-A2.

9. Clinical and Laboratory Standards Institute (CLSI). Methods for dilution antimicrobial susceptibility tests for bacteria that grow aerobically. Approved standard. $6^{\text {th }}$ ed. Wayne, PA: CLSI; 2003. p. M7-A6.

10. Clinical and Laboratory Standards Institute (CLSI). Reference method for broth dilution antifungal susceptibility testing of yeasts. Approved Standard. $3^{\text {rd }}$ ed. Wayne, PA: CLSI; 2008. p. M27-A3.

11. Clinical and Laboratory Standards Institute (CLSI). Susceptibility testing of Mycobacteria, Nocardiae, and other aerobic Actinomycetes. Approved Standard. $2^{\text {nd }}$ ed. M24-A2; 2008 .

12. Costa AF. Isolation and identification of the vegetables. In: Pharmacognosy. Lisboa: Calouste Gulbenkian; 1982. v. 3, p. 926-62.

13. Cowan MM. Plant products as antimicrobial agents. Clin Microbiol Rev. 1999;12:564-82.

14. Dall'Agnol R, Ferraz A, Bernardi AP, Albring DC, Sarmento L, Lamb L, et al. Antimicrobial activity of some Hypericum species. Phytomedicine. 2003;10:511-6.

15. Deba F, Xuan TD, Yasuda M, Tawada S. Chemical composition and antioxidant, antibacterial and antifungal activities of the essential oils from Bidens pilosa $\mathrm{L}$. var. Radiata. Food Control. 2008;19:346-52.
16. Delgado LF, Barbedo CJ. Tolerância à dessecação de sementes de espécies de Eugenia. Pesq Agropec Bras. 2007;42:265-72.

17. Estrada GS, Jiménez SI, Alarcon JC, Vargas LJ. Application of ultrasound in the dissolution of potential antiophidian compounds from two ethanolics extracts of two species of Heliconias. Ultrason Sonochem. 2010;17:756-9.

18. Fabry W, Okemo PO, Ansorg R. Antibacterial activity of East African medicinal plants. J Ethnopharmacol. 1998;60:79-84.

19. Garcia AD, Sánchez HR, Lizama RS. Citotoxicidad de extractos de plantas medicinales sobre la línea cellular de carcinoma de pulmón humano A549. Rev Cubana Farm. 2011;45:101-8.

20. Gonçalves MA, Lara TA, Pimenta LP. Alcaloides oxaporfínicos da madeira em Annona crassiflora Mart. In: 25ㄹ Reunião Anual da Sociedade Brasileira de Química; 20-23 de maio de 2002; Poços de Caldas, MG.

21. Kleymann G, Werling HOA. A generally applicable, high-throughput screening compatible assay to identify, evaluate, and optimize antimicrobial agents for drug therapy. J Biomol Screen. 2004;9:578-87.

22. Macedo-Costa MR, Diniz DN, Carvalho CM, Pereira MS, Pereira JV, Higino PJS. Eficácia do extrato de Myrciaria cauliflora (Mart.) O. Berg. (Jabuticabeira) sobre bactérias orais. Braz J Pharmacogn. 2009;19(2B):565-71.

23. Marques JM, Coelho PJA Ferreira MA, Amaral ZPS, Torres AC, Amorim JC. Estudo da variabilidade genética entre indivíduos de populações de Heliconia bihai and Heliconia rostrata. Brasília: EMBRAPA-CENARGEN; 2004.

24. Martins ER, Castro DM, Castellani DC, Dias JE. Plantas medicinais. Viçosa: UFV, 2000

25. Melo DLB. Dormência em sementes de Annona crassiflora Mart. [dissertação]. Lavras: Universidade Federal de Lavras; 2005.

26. Miranda RRS. Estudo fitoquímico e avaliação do potencial farmacológico de Maytenus salicifolia Reissek. [tese]. Belo Horizonte: Universidade Federal de Minas Gerais; 2007

27. Mohanty S, Cocki E. Evaluation of the antibacterial activity and toxicity of Myrciaria caulifloria methanolic leaf and fruit extracts. Internet J Microbiol. 2009;7(2). [cited 2011 May 5]. Available from: <http://www.ispub.com/journal/the_internet_journal of_microbiology/volume_7_number_2_26/article/evaluation-of-the-antibacterialactivity-and-toxicity-of-myrciaria-caulifloria-methanolic-leaf-and-fruit-extracts html>

28. Motsei ML, Lindsey KL, Van Staden J, Jãger AK. Screening of traditionally used South African plants for antifungal activity against Candida albicans. J Ethnopharmacol 2003;86:235-41

29. Nascimento GGF, Locatelli J, Freitas PC, Silva GL. Antibacterial activity of plant extracts and phytochemicals on antibiotic-resistant bacteria. Braz J Microbiol. 2000;31:24756

30. Oliveira FQ, Andrade-Neto V, Krettli AU, Brandão MGL. New evidencies of antimalarial activity of Bidens pilosa roots extract correlated with polyacetylene and flavonoids. J Ethnopharmacol. 2004;93:39-42.

31. Rajendran NK, Ramakrishnan J. In vitro evaluation of antimicrobial activity of crude extracts of medicinal plants against multi drug resistant pathogens. Biyoloji Bilimleri Araptyrma Dergisi. 2009;2:97-101

32. Reynertson KA, Wallace AM, Adachi S, Gil RR, Yang H, Basile MJ, et al. Bioactive depsides and anthocyanins from Jabuticaba (Myrciaria cauliflora). J Nat Prod. 2006;69:1228-30

33. Rojas JJ, Ochoa VJ, Ocampo S, Munoz JFL. Screening for antimicrobial activity of ten medicinal plants used in Colombian folkloric medicine: a possible alternative in the treatment of non nosocomial infections. BMC Complement Altern Med. 2006;6:1-6. 
CHAVASCO, J.M.; PRADO E FELIPHE, B.H.M.; CERDEIRA, C.D.; LEANDRO, F.D.; COELHO, L.F.L.; SILVA, J.J.; CHAVASCO, J.K. \& DIAS, A.L.T. - Evaluation of antimicrobial and cytotoxic activities of plant extracts from Southern Minas Gerais Cerrado. Rev. Inst. Med. Trop. Sao Paulo, 56(1): 13-20, 2014.

34. Santos SC, Ferreira FS, Damião AO, Barros TF, Rossi-Alva JC, Fernandez LG. Avaliação da atividade antibacteriana dos extratos de Avicennia schaueriana Stapf \& Leechm. ex Moldenke, Verbenaceae. Rev Bras Farmacogn. 2010;20:124-9.

35. Santos Pimenta LP, Pinto GB, Takahashi JA, Silva LGF, Boaventura MAD. Biological screening of annonaceous Brazilian medicinal plants using Artemia salina (Brine shrimp test). Phytomedicine. 2003;10:209-12.

36. Scalbert A. Antimicrobial properties of tannins. Phytochemistry. 1991;30:3875-83.

37. Schenkel EP, Gosmann G, Athayde ML. Saponinas. In: Simões CM, Schenkel EP, Gosmann G, Mello JCP, Mentz LA, Petrovick PR, org. Farmacognosia: da planta ao medicamento. 3 ed. Porto Alegre: UFRGS, Florianópolis: UFSC; 2002. p. 597-619.

38. Silva MV, Costa TR, Costa MR, Ferreira EC, Fernandes OFL, Santos SC, et al. Growth inhibition effect of Brazilian cerrado plant extracts on Candida species. Pharm Biol. 2001;39:138-41.
39. Souza-Moreira TM, Severi JA, Santos E, Silva VYA, Vilegas W, Salgado HRN, et al. Chemical and antidiarrheal studies of Plinia cauliflora. J Med Food. 2011;14:1590-6.

40. Stieven AC, Moreira JJS, Silva CF. Essential oils of uvaia (Eugenia pyriformis Cambess):evaluation of microbial and antioxidant activities. Eclet Quim. 2009;34(3):7-13

41. Tanaka JCA, Silva CC, Dias Filho BD, Nakamura CV, Carvalho JE, Foglio MA. Constituintes químicos de Luehea divaricata Mart. (Tiliaceae). Quím Nova. 2005;5:834-7.

42. Trabulsi LR, Althertum F. Microbiology. 4 ed. SãoPaulo: Atheneu; 2005.

43. Verdi LG, Brighente IMC, Pizzolatti MG. Gênero Baccharis (Asteraceae): aspectos químicos, econômicos e biológicos. Quím Nova. 2005;28:85-94.

Received: 12 January 2013

Accepted: 29 April 2013 